\title{
EVALUASI PROSES BELAJAR DAN PEMBELAJARAN DENGAN MODEL CIPP UNTUK MATA PELAJARAN PENJASORKES DI SEKOLAH MENENGAH KEJURUAN NEGERI 2 KOTA SERANG
}

\author{
Irwanto \\ Fakultas Keguruan dan IImu Pendidikan, Universitas Sultan Ageng Tirtayasa \\ JI. Raya Ciwaru No. 25 Ciwaru, Kota Serang-Banten, Indonesia \\ Email: irwanto.ir@untirta.ac.id \\ DOI: https://doi.org/10.36526/kejaora.v4i2.656
}

\begin{abstract}
ABSTRAK
Dalam penelitian ini bertujuan untuk mengetahui tingkat keberhasilan dalam belajar dan pembelajaran Pendidikan Jasmani, Olahraga dan Kesehatan (Penjasorkes) di SMK N 2 Kota Serang Banten serta dapat menghasilkan rekomendasi bagi para pengambil keputusan untuk menindaklanjuti program pembelajaran yang telah berjalan di SMK N 2 Kota Serang Banten tersebut. Model evaluasi yang digunakan dalam penelitian ini adalah model evaluasi CIPP dengan menggunakan teknik analisis statistik deskriptif dengan menggunakan persentase. Teknik ini digunakan untuk menganalisis data yang diperoleh dari hasil penyebaran angket dan menggunakan model yang dikembangkan oleh Daniel Stufflebeam yaitu CIPP (context, input, process, and product). Teknik pengumpulan data yang digunakan adalah observasi, wawancara, angket dan dokumentasi. Hasil penelitian ini menunjukkan bahwa variabel keseluruhan SMK N 2 Kota Serang Banten memperoleh persentase $84 \%$ dengan kriteria baik sekali. Berdasarkan hasil data tersebut, maka dapat disimpulkan bahwa secara keseluruhan pembelajaran pendidikan jasmani, olahraga dan kesehatan (Penjasorkes) di SMK N 2 Kota Serang Banten berada pada kriteria baik sekali, karena pembelajaran menggunakan teori dan praktik dengan perbandingan teori sebesar $30 \%$ dan praktik sebesar $80 \%$. Dari hasil ini menunjukkan bahwa pembelajaran pendidikan jasmani, olahraga dan kesehatan (Penjasorkes) di SMK N 2 Kota Serang merupakan salah satu sekolah terbaik.
\end{abstract}

Kata kunci: evaluasi, belajar dan pembelajaran, CIPP, Penjasorkes, SMK

\section{PENDAHULUAN}

Guru (pendidik) adalah salah satu faktor penentu keberhasilan pendidikan siswa, dimana guru berperan penting untuk menciptakan karakter dan kepribadian siswa dalam proses belajar mengajar di sekolah. Disamping itu guru Penjasorkes berperan aktif dalam segala proses pembelajaran yang bertujuan untuk meningkatkan kebugaran fisik bagi setiap siswa sehingga tujuan belajar Penjasorkes menjadi selaras dan sesuai dengan sasaran proses belajar mengajar. Sejalan dengan Peraturan Pemerintah Republik Indonesia Nomor 19 Tahun 2005 tentang Standar Nasional Pendidikan pasal 6 ayat 1 dijelaskan bahwa kurikulum untuk jenis pendidikan umum, kejuruan, dan khusus pada jenjang pendidikan dasar dan menengah terdiri atas kelompok mata pelajaran jasmani, olahraga dan kesehatan dengan cakupan sebagai berikut: Kelompok mata pelajaran jasmani, olahraga dan kesehatan pada SD/MI/SDLB, SMP/MTs/SMPLB,SMA/MA/SMALB/SMK/M AK, dimaksudkan untuk meningkatkan potensi fisik serta menanamkan sportivitas dan kesadaran hidup sehat.

Pendidikan Jasmani, Olahraga dan Kesehatan merupakan bagian integral dari pendidikan secara keseluruhan, bertujuan untuk mengembangkan aspek kebugaran jasmani, keterampilan gerak, keterampilan berpikir kritis, keterampilan sosial, penalaran, stabilitas emosional, tindakan moral, aspek pola hidup sehat dan pengenalan lingkungan bersih melalui aktivitas jasmani, olahraga dan kesehatan terpilih yang direncanakan secara 
sistematis dalam rangka mencapai tujuan pendidikan nasional (Samsudin, 2008).

Olahraga merupakan serangkaian gerak raga yang teratur dan terencana untuk memelihara gerak (mempertahankan hidup) dan meningkatkan kemampuan gerak (meningkatkan kualitas hidup). Olahraga merupakan alat untuk merangsang pertumbuhan dan perkembangan jasmani, rohani, dan sosial. Struktur anatomis Anthropometris dan fungsi fisiologisnya, stabilitas dan kecerdasan intelektualnya maupun kemampuannya bersosialisasi dengan lingkungan nyata lebih unggul pada siswasiswa yang aktif mengikuti kegiatan Pendidikan jasmani dan olahraga. Pelaksanaan pembelajaran pendidikan jasmani di SMK harus disesuaikan dengan kemampuan masing-masing anak dan pelaksanaan pembelajaran pendidikan jasmani yang diberikan harus sistematik, sesuai dengan karakteristik anak dan dikelola melalui pengembangan jasmani secara efektif dan efisien menuju pembentukan manusia seutuhnya. Evaluasi adalah suatu proses untuk menggambarkan peserta didik dan menimbangnya dari segi nilai dan arti (Zainal Arifin, 2014). Evaluasi adalah suatu proses bukan suatu hasil (produk). Hasil yang diperoleh dari kegiatan evaluasi adalah kualitas sesuatu, baik yang menyangkut tentang nilai atau arti, sedangkan kegiatan untuk sampai pada pemberian nilai dan arti itu adalah evaluasi.

Kegiatan pembelajaran sebagai sebuah sistem terdiri dari komponenkomponen guru, siswa, tujuan, bahan materi, fasilitas, strategi dan penilaian. Keseluruhan komponen tersebut tidak dapat berdiri sendiri, komponen satu dengan komponen lainnya saling berhubungan. Guru tidak dapat dilepaskan dari siswa yang menjadi sasaran dalam proses pembelajaran. Dalam proses pembelajaran yang dilaksanakan guru harus memiliki tujuan yang jelas, dengan berbagai bahan materi yang harus dipenuhi untuk mencapai tujuan yang telah direncanakkan. Dalam prosesnya seorang guru harus menggunakan berbagai cara sebagai strategi dalam menyajikan materi kepada siswa yang didukung oleh berbagai fasilitas memadai guna memudahkan siswa dalam belajar. Pada akhirnya guru harus dapat mengukur ketercapaian tujuan, maupun efektifitas proses pembelajaran melalui penilaian. Penilaian yang melingkupi seluruh aspek perkembangan siswa sebagaimana dimaksudkan di atas sebenarnya telah ada tidak hanya di dalam kurikulum 2013, tetapi ada di dalam setiap kurikulum sebelumnya. Penilaian sebagai komponen tidak terpisahkan dalam pembelajaran harus direncanakan guru sejak awal sebelum kegiatan pembelajaran dilaksanakan.

Penilaian yang direncanakan tersebut disusun sebagai acuan pendidik, maupun satuan pendidikan dalam mengukur ketercapaian tujuan pendidikan dan pembelajaran secara keseluruhan. Dalam Permendikbud nomor 66 tahun 2013 menyebutkan bahwa penilaian harus menjamin: (1) perencanaan penilaian peserta didik sesuai dengan kompetensi yang akan dicapai dan berdasarkan prinsip-prinsip penilaian; (2) pelaksanaan penilaian peserta didik secara profesional, terbuka, edukatif, efektif, efisien, dan sesuai dengan konteks sosial budaya dan (3) pelaporan hasil penilaian peserta didik secara objektif, akuntabel, dan informative (Permendikbud Nomor 66 tahun 2013).

Pada umumnya masih ditemukan bahwa guru mengembangkan instrument penilaian sesaat sebelum penilaian akan dilaksanakan (Sudijandoko, 2008). Guru seharusnya telah mempersiapkan seluruh rencana kegiatan pembelajaran termasuk mengembangkan instrument penilaian sebelum kegiatan pembelajaran dilaksanakan. Selain itu instrument penilaian yang dikembangkan guru masih didominasi oleh instrument penilaian yang digunakan untuk mengukur aspek kognitif. Instrumen penilaian untuk aspek psikomotorik apalagi untuk aspek afektif belum banyak dikembangkan. Hal ini terjadi dapat saja disebabkan oleh sistem yang berpengaruh terhadap sistem penilaian di madrasah/sekolah yang selama ini lebih banyak menekankan kepada aspek kognitif. Dapat pula dimungkinkan juga karena kurangnya kemampuan guru dalam mengembangkan instrument penilaian untuk aspek psikomotorik dan aspek afektif (Lutan, 1998). 
Salah satu masalah utama dalam pendidikan jasmani di Indonesia, hingga saat ini adalah belum efektifnya pengajaran pendidikan jasmani di sekolah-sekolah. Kondisi kualitas pengajaran pendidikan jasmani yang memprihatinkan di sekolah dasar, sekolah lanjutan dan bahkan perguruan tinggi telah dikemukakan dan ditelaah dalam berbagai forum oleh beberapa pengamat pendidikan jasmani dan olahraga. Kondisi ini disebabkan oleh beberapa faktor, diantaranya ialah terbatasnya kemampuan guru pendidikan jasmani dan terbatasnya sumber-sumber yang digunakan untuk mendukung proses pengajaran pendidikan jasmani (Samsudin, 2008: 11).

Pada dasarnya pendidikan jasmani dan olahraga (penjasorkes) merupakan bagian integral dari sistem pendidikan secara keseluruhan. Penjasorkes adalah proses interaksi antara peserta didik dan lingkungan melalui aktivitas jasmani yang disusun secara sistematik untuk menuju manusia Indonesia seutuhnya. Istilah penjasorkes mengandung dua makna, pertama, pendidikan untuk jasmani, kedua, pendidikan melalui aktivitas jasmani (Wuest \& Bucher, 2006: 125). Hal ini juga diperkuat oleh pendapat Zeigler (2009: 68) yang mengatakan bahwa fokus dari bidang pendidikan jasmani adalah aktivitas fisik yang mengembangkan, bukan sematamata aktivitas fisik itu sendiri. Selalu terdapat tujuan pengembangan manusia dalam program pendidikan jasmani. Pendidikan jasmani lebih fokus pada pengembangan fisik dan keterampilan siswa, dengan memakai sarana cabang-cabang olahraga untuk mencapai tujuan penjas. Fungsi olahraga sebagai salah satu sarana yang dipakai untuk melaksanakan proses penjasor. Selain itu, olahraga berfungsi sebagai sarana untuk (1) penyaluran emosi, (2) penguatan identitas, (3) kontrol sosial, (4) sosialisasi, (5) agen perubahan, (6) penyaluran kata hati, dan (7) mencapai keberhasilan (Wuest \& Bucher, 2006: 248-249).

Dengan demikian penjasorkes merupakan proses pendidikan melalui aktivitas jasmani dan olahraga sebagai sarana untuk mencapai tujuan pendidikan secara umum. Seperti dikatakan oleh Hardman dan Green (2005: 397) yang mengatakan bahwa pendidikan jasmani sebagai bagian dari kurikulum sekolah dengan mengembangkan kompetensi siswa secara fisik, rasa percaya diri, dan kemampuannya untuk menggunakan keterampilan di berbagai kegiatan. Penjasorkes memberikan kontribusi yang baik bagi kehidupan manusia, kontribusinya terhadap organ biologik, psikomotorik, afektif dan kognitif pelakunya. Selain itu, penjasor mampu mengembangkan pola hidup yang sehat dan aman, serta memiliki peran penting dalam mempengaruhi pola aktivitas dan kesehatan individu maupun masyarakat (Whitehead, 2001: 8). Sebagai bagian integral dari proses pendidikan secara umum, maka hendaknya penjasor dapat memberikan kesempatan kepada siswa untuk terlibat langsung dalam berbagai pengalaman belajar melalui aktivitas jasmani, bermain dan olahraga yang dilakukan secara sistematis (Winarno, 2004). Dari pengalaman belajar tersebut akan membina dan membentuk gaya hidup sehat dan aktif sepanjang hayat, yang pada akhirnya melalui penjasor diharapkan siswa akan memiliki pemahaman tentang (1) dirinya dan orang lain untuk terus mengembangkan diri dan berhubungan dengan orang lain, (2) nilai-nilai sosial dan keterampilan agar efektif dalam partisipasi, (3) budaya dan mampu menilai, (4) peran dan terampil berkomunikasi, (5) dunia sekitar dan cara beradaptasi, serta (6) peran keindahan dalam kehidupan dan mampu mengekspresikannya melalui aktivitas jasmani dan olahraga (Wuest \& Bucher, 2006: 62-63).

Menurut Leonard II (1998: 91) nilainilai yang terkandung dalam partisipasi olahraga antara lain dapat membangun watak, mengajarkan disiplln, mempersiapkan seseorang untuk kehidupan yang kompetitif, mengembangkan moral dan kemasyarakatan yang baik, dan menanamkan sifat-sifat kepribadian. Dengan demikian kedua proses sosial pada aktivitas olahraga saling mendukung dan berkaitan satu dengan yang lain, sehingga materi olahraga perlu dan wajib diajarkan di sekolah sejak SD sampai SMU/SMK bahkan Perguruan Tinggi. Melalui penjasor dapat sebagai sarana untuk mencapai tujuan pendidikan melalui aktivitas secara fisik (Kusnanik, Nasution \& Hartono, 2011). Tujuan pendidikan jasmani melalui 
kegiatan olahraga merupakan bagian integral dari seluruh proses pendidikan, yaitu sebagai upaya yang mendasar untuk mengembangkan fisik, mental, emosi, dan kesehatan sosial warga negara melalui media aktivitas fisik yang telah dipilih (Singer \& Dick, 2001: 13). Selanjutnya, Annarino, Cowell, Hazelton (2000: 60-64) menyatakan bahwa tujuan penjasorkes adalah meningkatkan semua siswa menjadi lebih sehat, berguna, dan berperan sebagai anggota masyarakat. Terbukti bahwa melalui aktivitas jasmani akan meningkatkan kemampuan organ tubuh, neuromuskuler, mengembangkan sikap pribadi sosial dan penyesuaiannya, kemampuan penafsiran dan intelektual, serta pengendalian emosi pelakunya. Dengan demikian secara mendasar tujuan olahraga di sekolah melalui penjasor mencakup seluruh aspek kepribadian siswa, yaitu aspek jasmani, rohani, makhluk sosial, dan aspek sebagai makhluk Tuhan (Nurhasan, 2011).

Kecenderungan masa depan yang semakin rumit dan kompleks tampaknya mengharuskan pendidikan untuk mampu menyiapkan siswa dalam menghadapi dunia nyata (Sutrisno, 2005: 36). Di sekolah, siswa perlu disadarkan tentang harapan yang mereka pikul, tantangan yang mereka hadapi dan kemampuan yang perlu mereka kuasai. Akan tetapi upaya perbaikan apapun yang dilakukan untuk meningkatkan kualitas pendidikan tidak akan memberikan sumbangan yang signifikan tanpa didukung oleh guru yang berkualitas (E. Mulyasa, 2007: 5). Pendidikan jasmani olahraga dan kesehatan yang diajarkan disekolah memiliki peranan sangat penting, yaitu memberikan kesempatan kepada perserta didik (Roji \& Eva, 2014). Untuk terlibat langsung dalam berbagai pengalaman belajar melalui aktivitas jasmani, olahraga, dan kesehatan yang terpilih yang dilakukan secara sistematis. Namun demikian pemahaman yang mendalam dan menyeluruh terhadap konsep saja ternyata tidak cukup untuk dapat mengajar pendidikan jasmani secara efektif (Firmansyah, 2009).

Para guru harus juga memahami model pembelajaran. Model pembelajaran sebernarnya adalah model belajar (models of teaching are really models of learning) Bruce \& Marsa (1996). Mereka mendefinisikan model pembelajaran sebagai pengorganisasian lingkungan yang dapat menggiring siswa berinteraksi dan mempelajari bagaimana belajar. Oleh karena setiap siswa adalah unik memiliki cara belajar yang beragam sesuai dengan perkembangan dan latar belajar sejarahnya, maka model pembeljaran yang berkembang sangat beragam. Bruce \& Marsha (1996) mengungkap tidak kurang dari 18 model pembelajaran, model-model tersebut dapat dipilih atau dikombinasikan untuk diterapkan dalam proses pembelajaran pendidikan jasmani. Proses pembelajaran pada dasarnya merupakan interaksi pedagogis antara guru, siswa, materi dan lingkungannya. Muara dari proses pembelajaran adalah siswa belajar. Secara garis besar proses ini dapat dibagi ke dalam tiga kategori pengelolahan yaitu pengelolaan rutinitas, pengelolaan inti proses belajar, serta pengelolaan lingkungan dan materi pembelajaran (Giriwijoyo, Santosa, Didik, 2012). Penjelasan yang dikemukakan di atas membuat peneliti ingin mengkaji lebih dalam dengan evaluasi model Context, Input, Process, Product (CIPP) dari implementasi kurikulum KTSP yang sudah berjalan sejak tahun 2006. Model CIPP pada prinsipnya konsisten dengan definisi evaluasi program pendidikan yang diajukan oleh komite tentang "Tingkatan untuk menggambarkan pencapaian dan menyediakan informasi guna pengambilan keputusan alternative" (Sukardi, 2009: 63). KTSP dari segi evaluasi konteks (context) menitik beratkan tujuan implementasi KTSP dan sumber dukungan yang ada dalam implementasi kurikulum (Suherman, 2001).

Evaluasi masukan (input) meberi perencanaan yang efektif terhadap keberhasilan dari pelaksanaan kurikulum. Orientasi utama evaluasi masukan (input) ialah mengemukakan suatu perencanaan yang dapat mencapai apa yang diinginkan lembaga tersebut. Evaluasi proses (process) baru dapat dilakukan apabila inovasi kurikulum tersebut telah dilaksanakan. Evaluasi hasil (product) ialah untuk menetukan sejauh mana kurikulum yang diimplementasikan telah dapat memenuhi kebutuhan kelompok yang menggunakan setelah program berjalan dan tingkat 
keberhasilan yang sudah dicapai atau apa yang akan dihasilkan. Dengan adanya permasalahan tersebut, peneliti akan mengevaluasi belajar dan pembelajaran Penjasorkes di SMK N 2 Kota Serang Banten dengan pendekatan model CIPP (context, input, process, product).

\section{METODE}

Penelitian ini bertujuan untuk mengetahui komponen-komponen evaluasi belajar dan pembelajaran untuk mata pelajaran penjasorkes di SMK N 2 Kota Serang yang meliputi context, input, process, dan product. Penelitian evaluasi program ini bertempat di Sekolah Menengah Kejuruan Negeri 2 Kota Serang Banten. Pendekatan penelitian yang digunakan adalah menggunakan pendekatan deskriptif kualitatif dengan tujuan untuk mendeskripsikan dan menilai hasil program belajar dan pembelajaran penjasorkes di SMK N 2 Kota Serang Banten. Dalam evaluasi ini akan dilakukan penggalian data secara intensif kemudian dianalisa dengan cermat pada tiaptiap tahapan (Maksum, 2012).

Tahapan penelitian evaluasi program pembelajaran penjasorkes di SMK N 2 Kota Serang mengacu pada alur model CIPP (Context, Inputs, Process, Product) dari Stufflebeam (2014). Pengumpulan data dalam penelitian ini menggunakan instrumen penelitian berupa angket atau kuisioner, wawancara, observasi, sedangkan dokumentasi berupa arsip yang digunakan sebagai data pendukung atau data sekunder (Arikunto, 2014). Data yang yang diperoleh dalam penelitian ini adalah data primer dan data skunder. Data primer diperoleh dari wawancara dan angket siswa, sedangkan data skunder diperoleh dari dokumen yang relevan dengan masalah yang diteliti (Arikunto, 2006). Sedangkan data kuantitatif dianalisis menggunakan analisis statistik deskriptif persentase. Adapun rumusnya adalah sebagai berikut:

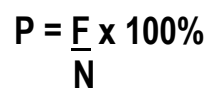

Keterangan:

$P$ : Persentase

F : Jumlah skor yang dicari dari seluruh responden

$\mathrm{N}$ : Jumlah skor maksimal dari seluruh responden
Data yang terkumpul akan dipisahkan sesuai klasifikasinya, data yang berupa angka-angka akan tergolong data kuantitatif dan data yang berupa kata atau kalimat tergolong data kualitatif (Sugiyono, 2013). Data kuantitatif akan dilakukan dengan kuesioner menggunakan skala likert dan dikotomi "ya" dan "tidak" dan diperkuat dengan jawaban terbuka dari responden yang akan ditafsirkan dalam persentase. Hasil analisis kedua skala tersebut akan diklasifikasikan seperti pada Tabel 1 sebagai berikut:

\begin{tabular}{ccc}
\multicolumn{3}{c}{ Tabel 1. Kriteria Persentase } \\
\hline No & Rentangan Persentase & Kriteria \\
\hline 1 & $81 \%-100 \%$ & Baik sekali \\
2 & $61 \%-80 \%$ & Baik \\
3 & $41 \%-60 \%$ & Cukup \\
4 & $21 \%-40 \%$ & Kurang \\
& $<21 \%$ & Kurang Baik \\
\hline
\end{tabular}

\section{HASIL}

\section{Variabel Context}

Hasil penelitian menemukan bahwa variabel context keseluruhan SMK N 2 Kota Serang Banten memperoleh persentase 83\% dengan kriteria baik sekali. Hal ini menunjukkan bahwa guru yang mengajar Penjasorkes di SMK N 2 Kota Serang Banten tersebut telah memahami kebutuhankebutuhan dalam mengajar seperti perangkat pembelajaran yang dibutuhkan. Selain itu, guru Penjasorkes di SMK N 2 Kota Serang Banten juga memahami tujuan pembelajaran pada pendidikan jasmani, olahraga dan kesehatan (penjasorkes).

\section{Variabel Input}

Secara evaluatif hasil variabel input SMK N 2 Kota Serang Banten memperoleh persentase $92 \%$ dengan kriteria baik sekali, input guru maupun input siswa berperan sangat penting terhadap ketercapaian tujuan pembelajaran. Dengan guru yang sesuai dengan kompetensi bidangnya maka proses belajar dan pembelajaran akan dapat terlaksana dengan baik atau setidaknya apabila belum seluruhnya tercapai, kesalahan-kesalahan dapat diminimalisir dan diperbaiki (Faizal, 2019). Bagi siswa yang mempunyai latar belakang dengan tingkat intelektual yang baik maka akan memudahkan siswa dalam belajar gerak, 
karena dalam pendidikan jasmani aspek keterampilan motorik sangat diperlukan. Secara evaluatif hasil variabel input untuk SMK N 2 Kota Serang Banten memperoleh $72 \%$ dengan kriteria baik.

\section{Variabel Process}

Dalam sebuah pembelajaran yang baik peran proses merupakan hal yang sangat penting. Sebuah proses terdapat 3 tahapan yang harus selalu ada yaitu perencanaan, pelaksanaan dan evaluasi dalam mengajar. Secara evaluatif hasil variabel process untuk SMK N 2 Kota Serang Banten memperoleh $83 \%$ yang dengan kriteria baik sekali.

\section{Variabel Product}

Hasil penelitian menunjukkan bahwa evaluatif hasil variabel product untuk SMK N 2 Kota Serang memperoleh $75 \%$ yang dengan kriteria baik.

\section{Variabel Keseluruhan CIPP}

Secara keseluruhan hasil persentase variabel CIPP pada evaluasi program pembelajaran pendidikan jasmani kelas 2 SMK N 2 Kota Serang Banten, mendapat $84 \%$ yang apabila diakumulasikan berpredikat baik sekali.

\section{PEMBAHASAN \\ Variabel Context}

Berdasarkan hasil dari angket berupa persentase juga diperkuat data wawancara berhubungan dengan kebutuhan dan tujuan pembelajaran Penjasorkes yaitu kebutuhan utama yang harus dipenuhi dalam pembelajaran yaitu kebutuhan teknis dan non-teknis. Kebutuhan teknis meliputi perangkat pembelajaran sebagai pedoman dalam pembelajaran dan sarana prasarana sedangkan kebutuhan non-teknis meliputi persiapan mental, psikologis peserta didik dan segala kemungkinan yang akan terjadi pada pembelajaran, misalnya gangguan alam, penanganan siswa yang bermasalah dan sebagainya.

\section{Variabel Input \\ Berdasarkan hasil dari angket yang berupa persentase juga diperkuat data}

wawancara yang berhubungan dengan kondisi awal siswa dan faktor yang mempengaruhi pembelajaran yang dapat diambil kesimpulan bahwa kondisi awal siswa mempunyai pengaruh terhadap tujuan pembelajaran Penjasorkes, karena sangat berperan aktif dalam mempengaruhi karena siswa yang baik dari segi intelektual, sosial dan emosional akan mempermudah guru dalam menyampaikan materi atau mengajar.

Selain itu kondisi awal siswa juga dipengaruhi oleh pendidik, bukan hanya siswa, guru juga dituntut untuk memperhatikan aspek psikologis siswa khususnya di lapangan, oleh karena itu, guru harus mempunyai kompetensi yang jelas. Maksudnya, guru mempunyai kompetensi lulusan pendidikan jasmani dan kesehatan karena guru yang tidak sesuai bidangnya maka akan kesulitan khususnya dalam pengelolaan kelas, skill dan mental dalam mengajar mata pelajaran penjasorkes.

\section{Variabel Process}

Dari hasil variabel process di atas dan hasil wawancara terjadi sebuah kesesuaian dalam hal tercapainya target yang dinginkan yaitu tentang rencana dalam pembelajaran yang tidak dapat sepenuhnya dapat sesuai. Ini disebabkan karena kondisi dan situasi dalam belajar misalnya alokasi waktu, kegiatan sekolah dan cuaca. Sarana dan prasarana tidak boleh dijadikan alasan untuk tidak melakukan pembelajaran yang menyenangkan karena dengan memanfaatkan sarana dan prasarana yang dimodifikasi siswa akan lebih tertarik, menantang dan menyenangkan.

Hal yang harus diperhatikan yaitu siswa mempunyai kesempatan untuk mengeksploitasi gerak secara bebas meskipun terkendala sarana dan prasarana. Berhubungan dengan hambatan yang ditemukan dalam pembelajaran yaitu berhubungan dengan tuntutan nilai akademik yang baik, motivasi belajar siswa, cuaca dan sarana prasarana.

\section{Variabel Product}

Berdasarkan hasil yang ingin dicapai dalam pembelajaran yaitu tercapainya aspek pembelajaran yaitu afektif, kognitif, psikomotor dan fisik. Hasil penelitian 
menunjukkan bahwa keempat aspek tersebut tercapai dengan baik. Hal ini dibuktikan dengan hasil belajar siswa yang baik.

\section{KESIMPULAN}

Berdasarkan hasil dan pembahasan, maka dapat di simpulkan: Dalam context evaluasi pembelajaran Penjasorkes di SMK N 2 Kota Serang Banten yang berhubungan dengan kebutuhan dan tujuan pembelajaran memperoleh kriteria baik sekali; variable input evaluasi belajar dan pembelajaran Penjasorkes di SMK N 2 Kota Serang Banten yang berhubungan sumber daya manusia, sarana dan prasarana memperoleh kriteria baik sekali; Dalam process evaluasi belajar dan pembelajaran Penjasorkes di SMK N 2 Kota Serang Banten yang berhubungan dengan perencanaan, pelaksanaan dan evaluasi pembelajaran memperoleh kriteria baik sekali; Dalam product evaluasi program pembelajaran Penjasorkes di SMK N 2 Kota Serang Banten yang berhubungan dengan hasil belajar siswa (afektif, psikomotor, kognitif, psikomotor) memperoleh kriteria baik. Maka dapat diputuskan bahwa evaluasi belajar dan pembelajaran Penjasorkes di SMK N 2 Kota Serang Banten secara keseluruhan dengan kriteria baik sekali.

\section{SARAN}

1. Guru Penjasorkes harus lebih memfokuskan kegiatan evaluasinya pada sasaran-sasaran evaluasi yang menjadi tujuan pembelajaran Penjasorkes, khususnya yang berkaitan dalam upaya meningkatkan potensi fisik, menanamkan sportivitas dan kesadaran hidup sehat.

2. Lembaga Pendidikan Tenaga Kependidikan (LPTK) yang menghasilkan Guru-guru Penjasorkes perlu meningkatkan kecakapan mahasiswanya dalam bidang evaluasi, bukan saja berupa pengukuran keterampilan-keterampilan olahraga tetapi juga pengukuran lain seperti pengukuran-pengukuran Penjas (physical education measurement), psikometri dan sosiometri.

\section{Ucapan Terima Kasih}

Dalam penelitian, peneliti mengucapkan banyak terima kasih kepada kepala sekolah SMK N 2 Kota Serang Banten yang telah memberikan ijin untuk melakukan penelitian, Guru Penjasorkes di SMK N 2 Kota Serang Banten serta siswa-siswi SMK N 2 Kota Serang.

\section{DAFTAR PUSTAKA}

Annarino, AA., Cowell, CC., Hazelton, HW. (2000). Curriculum Theory and Design in Pliysical Education. London: The C.V. Mosby Company.

Arikunto, S. (2006). Prosedur Penelitian. Jakarta: PT. Renika Cipta.

Arikunto, S. (2014). Evaluasi Program Pendidikan. Jakarta: Bumi Aksara.

E. Mulyasa. (2007). Kurikulum Tingkat Satuan Pendidikan Sebuah Panduan Praktis. Bandung: Remaja Rosdakarya.

Faisal, K. H. (2019). Evaluasi Pembelajaran Penjasorkes SMP Negeri di Kecamatan Ampelgading Kabupaten Malang. Jurnal Kejaora, Volume 4 Nomor 1, April 2019, ISSN 2541-5042. Prodi Pendidikan Olahraga, Universitas Muhammadiyah Jember.

Firmansyah, H. (2009). Hubungan Motivasi Berprestasi Siswa dengan Hasil Belajar Pendidikan Jasmani. Jurnal IImiah Dosen Pendidikan Jasmani. Volume 6, Nomor 1, April 2009. FIK UNY.

Giriwijoyo, H. Y. S. Santosa., Didik Zafar Sidik. (2012). IImu Faal Olahraga (Fisiologi Olahraga). Bandung: PT. Remaja Rosdakarya.

Kusnanik, N. W., Nasution, J., \& Hartono, S. (2011). Dasar-Dasar Fisiologi Olahraga. Unesa: University Press.

Leonard II, Wilbert Marcellus. (1998). A Social Perspective of Sport. Minneapolis Minnesota: Burgess Publishing Company.

Lutan, Rusli. (1998). Manusia dan Olahraga. Bandung: ITB Dan FPOKI IKIP Bandung.

Maksum, A. (2012). Metodologi Penelitian dalam Olahraga. Surabaya: Unesa University Press.

Nurhasan. (2011). Menjaga Kebugaran Jasmani. Gresik: Abil Pustaka.

Peraturan Menteri Pendidikan dan Kebudayaan Republik Indonesia 
Nomor 66 Tahun 2013 tentang

Standar Penilaian Pendidikan.

Jakarta.

Peraturan Pemerintah Republik Indonesia Nomor 19 Tahun 2005 Tentang Standar Nasional Pendidikan. Jakarta.

Roji \& Eva, Y. (2014). Pendidikan Jasmani Olahraga dan Kesehatan. Jakarta: Pusat Kurikulum dan Perbukuan, Balitbang, Kemendikbud.

Samsudin. (2008). Pembelajaran Pendidikan Jasmani Olahraga dan Kesehatan SMA/MA. Edisi Pertama. Jakarta: Litera.

Singer, R.N., Dick, W. (2001). Teaching Physical Education: A System Approach Boston: Houghton Mifflin Company.

Stufflebeam, Daniel L. dan Corin, Chris L.S. (2014). Evaluation Theory, Models, \& Applications. San Fransisco: Jossey Bass.

Sudijandoko, A. (2008). "Evaluasi Pendidikan Jasmani dalam Pendekatan Portofolio". Universitas Negeri Surabaya: Jurnal Pelangi IImu, Vol.2, No.2 Juli-Desember 2008. Diunduh pada tanggal 21 April 2015 dari http://pelangiilmu.jurnal.unesa.ac.id/.

Sugiyono. (2013). Metode Penelitian Kuantitatif, Kualitatif dan $R$ \& $D$. Bandung: Alfabeta.

Suherman, Wawan S. Pengembangan Kurikulum Pendidikan Jasmani. Yogyakarta: FIK UNY, 2001.

Sukardi. (2009). Evaluasi Pendidikan Prinsip Dan Operasionalnya. Jakarta: Bumi Aksara.

Sutrisno. (2005). Perkembangan Olahraga Terkini. Jakarta: PT. Raja Grafindo Persada.

Whitehead, M. The Concepts of Physical Literacy. (2001). The British Journal of Teaching Physical Education, Spring 2001.

Winarno, M. E. (2004). Evaluasi dalam Pendidikan Jasmani dan Olahraga. Jakarta: Center For Human Capacity Development.
Wuest, Deborah A. \& Bucher, Charles A. (2006). Foundations of Physical Education and Sport. St. Louis, Missouri: Mosby-Year Book, Inc.

Zainal, A. (2014). Evaluasi Pembelajaran Prinsip, Teknik, Prosedur. Bandung: PT. Remaja Rosdakarya.

Zeigler, Earle F. (2009). International and Comparative Physical Education and Sport. Canada: Trafford. 